\title{
SPODNOKARBONŠTÍ MLŽI DRAHANSKÉ VRCHOVINY (KULMSKÁ FACIE) A JEJICH STRATIGRAFICKÝ VÝZNAM
}

\author{
Lower Carboniferous bivalves from the Drahany Upland (Culm facies) and their \\ statigraphical significance
}

\author{
Martin Kováček', Tomáš Lehotský1,2 \\ ${ }^{1}$ Katedra geologie PřF UP, 17. listopadu 12, 77146 Olomouc \\ ${ }^{2}$ Vlastivědné muzeum v Olomouci, nám. Republiky 5, 77173 Olomouc; e-mail: lehotsky@prfnw.upol.cz
}

(24-41 Vyškov)

Key words: Moravosilesicum, Lower Carboniferous, Myslejovice Formation, Bivalvia, stratigraphy

\begin{abstract}
The Drahany Upland is built of a flysch sequence of Lower Carboniferous age (shale, greywackes, conglomerates), and a preflysch sequence of Devonian to Lower Carboniferous age (spilites, carbonates, shales). Lower Carboniferous black shales are known by goniatites and bivalvian assemblages, also fossil traces. According to the Żakowa (1971) methodology were determined species of bivalves of the genus Posidonia and Septimyalina. Amler (1994) describes the morphology of the bivalve genus Streblochondria. So far was from the Culm sites od Drahany Upland determined 18 kinds of Lower Carboniferous bivalves represented by following species: Posidonia becheri, Posidonia corrugata, Posidonia kochi, Posidonia trapezoedra, Posidonia radiata, Septimyalina sublamellosa, Septimyalina lamellosa, Septimyalina cf. minor, Dunbarella mosensis, Streblochondria patteiskyi, Streblochondria praetenuis, Sanguinolites sp., Janeia böhmi, Polidevcia cf. sharmani, Anthraconeilo oblongum, Palaeoneilo luciniforme and Edmondia sp. These genera originated from localities of Myslejovice Formation (i. e. Opatovice, Dédice, Pístovice, Nemojany, Ježkovice, Radslavice and Myslejovice). Lower Carboniferous marine bivalves can be also used for correlation of goniatites zones in the Upper Viséan of Myslejovice Formation. Correlation table is adapted from Amler (2004). Correlation of bivalve zones to goniatite zones has proven to be useful. Due to the very variable conditions of the various locations the deviations can be partly caused by incompleteness of the fossil record from the specified horizons.
\end{abstract}

Úvod

Spodnokarbonská fauna myslejovického souvrství drahanského kulmu byla doposud předmětem paleontologických prací, které se vesměs zabývaly především goniatity (Kumpera - Lang 1975, Lehotský 2008) a fosilními stopami (Lang et al. 1979). Další fauna byla zmiňována pouze jako doprovodná. Prozatím nebyla vydána rozsáhlejší práce, která by se systematicky zabývala mlží faunou. Současně se také předpokládají možnosti stratigrafického využití spodnokarbonských mlžů a korelace s detailnější biostratigrafií podle goniatitů (obr. 1).

Oblast Drahanské vrchoviny spadá regionálně-geologicky do moravskoslezské jednotky Českého masivu. Její převážná část je tvořena monotónními sledy hornin moravskoslezského kulmu. Dvořák (1966) na základě odlišného faciálního vývoje vyčleňuje na Drahanské vrchovině souvrství myslejovické, rozstáňské a protivanovské. Myslejovické souvrství tvoří facie kosířských drob, studnických břidlic, račických a lulečských slepenců. Četná fosilní fauna, flora a ichnofauna myslejovického souvrství je vázána především na jemnozrnné droby, prachovce a jílové břidlice. Její nálezy se soustředují v jihovýchodní části Drahanské vrchoviny do okolí Vyškova a Opatovic. Dále se paleontologické lokality nacházejí v blízkosti obcí Nemojany, Pístovice, Dědice, Rychtářov, Ježkovice, Myslejovice a Radslavice. Na těchto lokalitách intenzivně sbíral ředitel Vyškovského gymnázia V. Lang, který nashromáždil rozsáhlou sbírku fosilií. Kolekce je dnes uložena ve Vlastivědném muzeu v Olomouci.

\section{Materiál a metodika}

Z rozsáhlé kolekce spodnokarbonské fauny bylo revidováno 506 kusů fosilií mlžů. Jedná se o kompletní jedince, lumachely a fragmenty misek. K určení jednotlivých druhů byly pozorovány morfologické rysy a měřeny rozměry misek. Podle metodiky Żakowe (1971) byly zkoumány druhy mlžů rodu Posidonia a Septimyalina. Amler (1994) popisuje morfologii mlžů rodu Streblochondria.

\section{Mlži myslejovického souvrství drahanského kulmu}

Prozatím bylo z kulmských lokalit Drahanské vrchoviny určeno 18 druhů spodnokarbonských mlžů, jejichž zástupci jsou sdruženi do 4 podtř́íd a to Pteriomorphia, Heteroconchia, Cryptodonta a Paleotaxodonta, z nichž jsou nejpočetnější zástupci podtřídy Pteriomorphia.

Podtř́da: Pteriomorphia BeURLEN, 1944

Rod: Posidona BRONN, 1828

Posidonia becheri BRONN, 1828

Obr. 2-8.

Ekvilaterární a inekvivalvní misky velmi malých rozměrů (juvenilní stadia) až značně velkých rozměrů. Pravé misky bývají obecně plošší a na anterio-ventrálním okraji lze pozorovat zbytky po bysálním zářezu. Zadní část misky je zakulacená. Skulptura misek je tvořena koncentrickými př́růstkovými žebry. Výrazné a ostré vrcholy misek někdy chybí.

Výskyt: Dědice K, Hamiltony 1, Ježkovice 5, Ježkovice Db, Ježkovice K, Ježkovice R, Nemojany Bl. dol., Nemojany $\mathrm{H}$, Nemojany Ch, Olšany, Opatovice 2, Opatovice 8, Opa- 


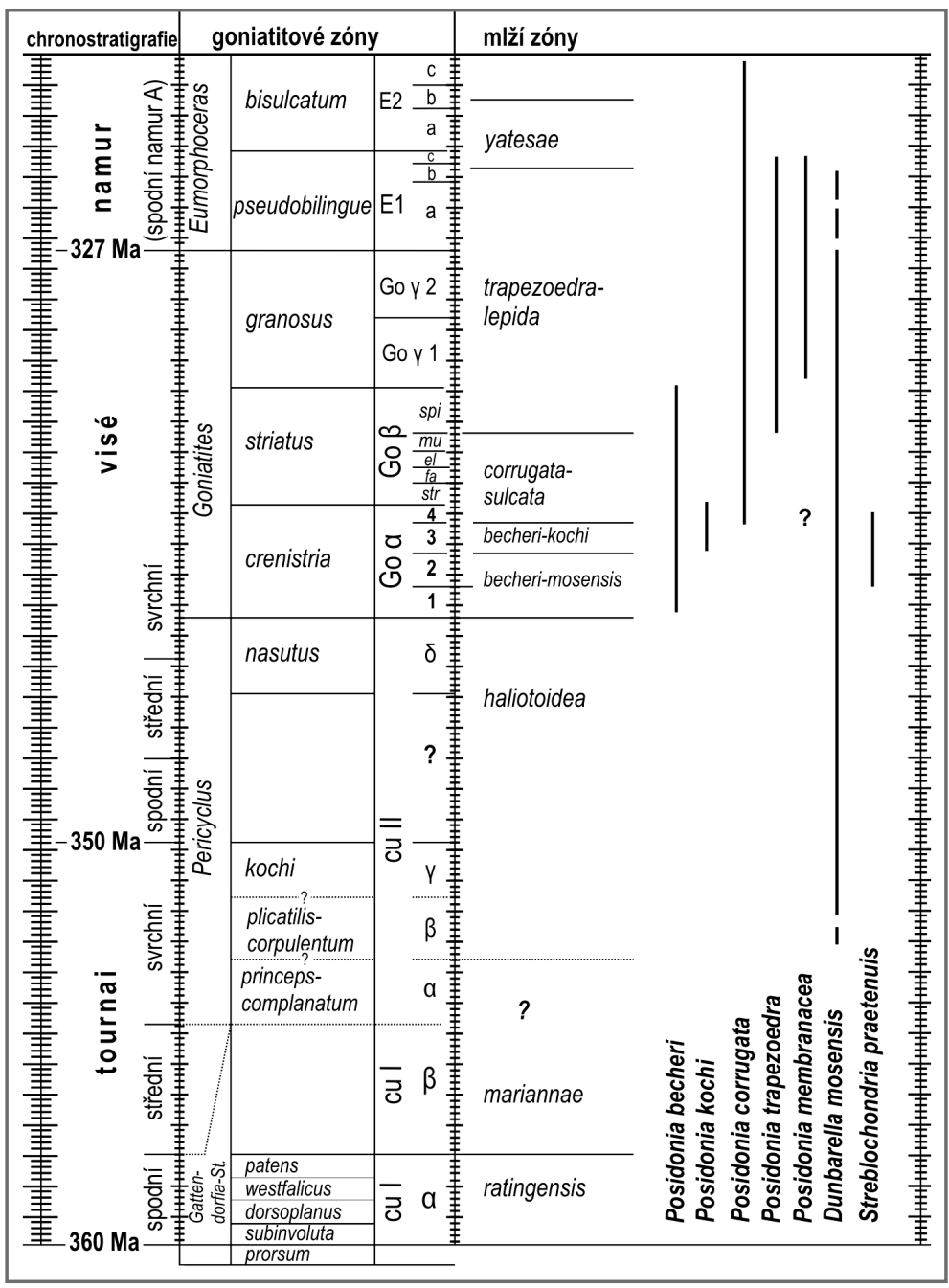

Obr. 1: Stratigrafické rozpětí spodnokarbonských mlžů kulmské facie Evropy a srovnání s goniatitovými zónami (upraveno podle Amlera 2004), chronostratigrafie podle Korna (2010).

Fig. 1: Stratigraphic range of the Lower Carboniferous bivalves of Europe Culm facies compared with goniatite zones (modified according to Amler 2004), chronostratigraphy according to Korn (2010).

tovice 10, Opatovice 11, Pístovice K, Pístovice Š1, Pístovice ŽII, Radslavice, Rychtářov 3, Rychtářov 6.

Posidonia corrugata ETHERIDGE, 1874

Obr. 2-7a, obr. 2-7b.

Ekvilaterární a inekvivalvní misky robustnějších rysů, obvykle však subovátní až elongátní. Nejvíce klenuté ve střední a vrcholové části. Dorzální okraj je krátký a jednoduchý, poměrně málo se zachovávají ouška. Vrcholy jsou výrazné, vyklenuté až ostré, u elongátních forem je zadní a přední okraj mírně konvexní. Povrch je tvořen nepravidelnou skulpturou koncentrických přírůstkových linií.

Výskyt: Ježkovice R, Nemojany Ch, Olšany, Opatovice 11, Opatovice 1a, Opatovice 2, Opatovice 4, Opatovice 6, Opatovice 8.

\section{Posidonia kochi KoEnEN, 1879}

Obr. 2-3.

Misky jsou zpravidla malých rozměrů. Jsou výrazně protažené ve směru růstu misky. Dorsální okraj je krátký a jednoduchý. Zadní okraj je zešikmen vưči přednímu a ventrální část je elongátní. Misky jsou vesměs ploché, nejvíce konvexní ve středu. Povrch je tvořen hustými koncentrickými liniemi. Poškozena při fosilizaci jsou zejména přední ouška, která mívají zaoblený okraj.

Výskyt: Dědice K, Opatovice 1, Opatovice 1a, Opatovice 2, Opatovice 4, Opatovice 6, Opatovice 8, Opatovice 10, Opatovice 11, Pístovice Š1.

\section{Posidonia trapezoedra RUPRECHT, 1937}

Obr. 2-4, obr. 2-5.

Morfologicky variabilní misky, zpravidla prodloužené ve směru výšky. Misky bývají obvykle ploché, dorzální okraj krátký a jednoduchý. Přední okraj s malým ouškem je téměř kolmý k dorzálnímu okraji. Skulpturu tvoří koncentrické př́růstkové linie.

Výskyt: Dědice K, Opatovice 1, Opatovice 1a, Opatovice 4, Opatovice 6, Opatovice 8 .

\section{Posidonia radiata HIND, 1901}

Obr. 2-6a, obr. 2-6b.

Misky jsou především malých rozměrů, nejvíce konvexní v anterio-dorzální části, protažené a zešikmené $\mathrm{v}$ jednom směru. Povrch tvoří výraznější radiální žebrování a méně výrazná koncentrická žebra. Pokud se zachovává přední ouško, je velké a spolu s dorsálním okrajem tvoří jednu linii.

Výskyt: Opatovice 1a, Opatovice 4, Opatovice 8.

\section{Rod: Septimyalina NewELL, 1942}

Septimyalina sublamellosa ETHERIDGE, 1878

Středně velké misky. Vrcholy jsou drobné, dorzální okraj je zakulacený a mírně konvexní. Misky jsou vesměs ploché, úzké, inekvivalvní a prosoklinické. Přední okraj je mírně konkávní s malým bysálním sinusem. Zadní okraj je široce konvexní a prochází téměř paralelně s okrajem předním. Dorzální okraj je téměř rovný. Povrch je tvořen jemnými koncentrickými striemi a nepravidelnými koncentrickými liniemi.

Výskyt: Ježkovice B, Lhota 1, Nemojany Ch, Opatovice 1, Opatovice 1a, Opatovice 1b, Opatovice 2, Opatovice 4, Opatovice 6, Opatovice 8, Opatovice 10.

\section{Septimyalina cf. lamellosa KONINCK, 1842}

Misky pouze malých rozměrů do $5 \mathrm{~mm}$. Misky jsou ve střední části zúžené, inekvilaterální a silně prosoklinické. Postero-ventrální okraj je elongátní, postero-dorzální okraj naopak zaoblený. Vrcholy jsou drobné, zámkový okraj je téměř rovný, pouze u některých vzorků mírně, nepravidelný. Povrch je tvořen špatně zřetelnými přírůstkovými liniemi. Na předním okraji, v místě, kde je nejvíce konkávní, lze pozorovat bysální sinus. 
Výskyt: Opatovice 1a, Opatovice 2, Opatovice 4, Opatovice 6, Opatovice 10, Opatovice 11.

Septimyalina cf. minor BROWN, 1841

Misky malých rozměrů do $5 \mathrm{~mm}$. Misky jsou inekvivalvní a prosoklinické. Misky jsou mírně klenuté, klenutí probíhá středem misek. Dorzální okraj je rovný, se zadním okrajem svírá tupý úhel. Zadní okraj je zakulacený. Vrchol je rozšířen až k přednímu okraji misky. Povrch je tvořen špatně zřetelnými koncentrickými liniemi.

Výskyt: Dědice K, Luleč, Opatovice 1, Opatovice 2, Opatovice 4, Opatovice 10, Opatovice 11.

Rod: Dunbarella NEWELL, 1938

Dunbarella mosensis KoNINCK, 1885

Obr. 2-2.

Misky malých rozměrů subkvadratického tvaru. Vrcholy jsou drobné, umístěné subcentrálně, pouze lehce převyšují zámkový okraj. Misky jsou ve svých rozměrech stejné na délku i šírku. Přední ouško je od předního okraje odděleno výraznou rýhou, zatímco zadní ouško je bez zářezu a je ploché. U oušek nejsou patrné umbonální záhyby. Misky mají radiální a koncentrickou skulpturu. Radiální žebra jsou široká, na ouškách je koncentrická skulptura vždy jemnější a méně výrazná. Ta je tvořena tenkými liniemi oddělenými širokými meze-

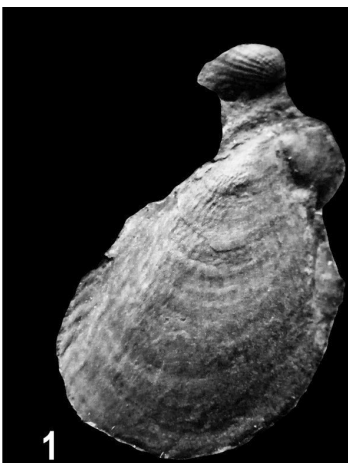

1

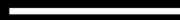

2

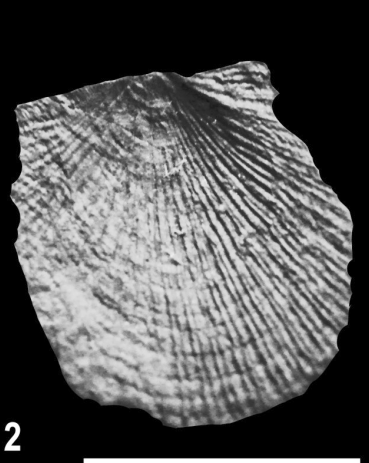

3

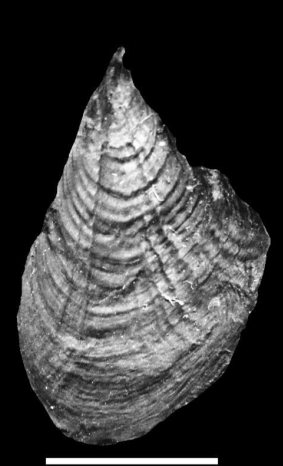

4
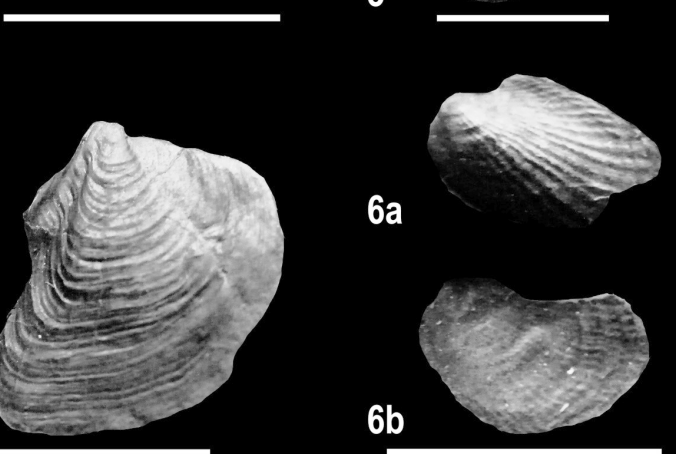

$6 a$

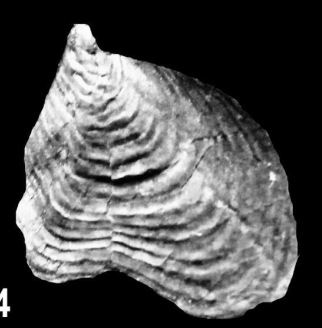

5

$6 b$

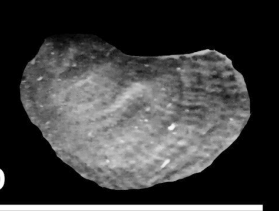

7 a

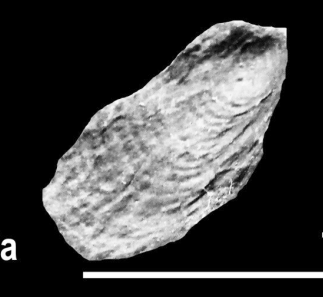

$7 \mathrm{~b}$

Obr. 2: Stratigraficky významné druhy mlžů jv. části Drahanské vrchoviny: 1. Streblochondria praetenuis, Opatovice 8, i. č. 3659, levá miska, pozitiv. 2. Dunbarella mosensis, Myslejovice, i. č. 8854, levá miska, negativ. 3. Posidonia kochi, Opatovice 10, i. č. 4124, levá miska, pozitiv. 4. Posidonia trapezoedra, Opatovice 1a, i. č. 1093, pravá miska, pozitiv. 5. Posidonia trapezoedra, Opatovice 4, i. č. 19672/1, pravá miska, pozitiv. 6a. Posidonia radiata, Opatovice 8, i. č. 4382, levá miska, pozitiv. 6b. Posidonia radiata, levá miska, negativ. 7a. Posidonia corrugata, Opatovice 2, i. č. 11001, pravá miska, negativ. 7b. Posidonia corrugata, pravá miska, pozitiv. 8. Posidonia becheri, Pístovice ŽII, i. č. 3297/2, levá miska, pozitiv. Grafické měřítko = 1cm.

Fig. 2: Stratigraphic important species of molluscs in SE part od Drahany upland: 1. Streblochondria praetenuis, Opatovice 8, i. n. 3659, left valve, positive. 2. Dunbarella mosensis, Myslejovice, i. n. 8854, left valve, negative. 3. Posidonia kochi, Opatovice 10, i. n. 4124, left valve, positive. 4. Posidonia trapezoedra, Opatovice 1a, i. n. 1093, right valve, positive. 5. Posidonia trapezoedra, Opatovice 4, i. n. 19672/1, right valve, positive. 6a. Posidonia radiata, Opatoviee 8, i. n. 4382, left valve, positive. 6b. Posidonia radiata, left valve, negative. 7a. Posidonia corrugata, Opatovice 2, i. n. 11001, right valve, negative. 7b. Posidonia corrugata, right valve, positive. 8. Posidonia becheri, Pístovice ŽII, i. n. 13297/2, left valve, positive. Graphics scale $=1 \mathrm{~cm}$. rami, $\mathrm{v}$ místech překřižení $s$ radiálními žebry tvoří hrbolky.

Výskyt: Myslejovice, Opatovice 10, Ježkovice R.

Rod: Streblochondria NEWELL, 1938

Streblochondria patteiskyi NICOLAUS, 1963

Misky oválného tvaru, nejvíce konvexní ve střední části. Ventrální okraj je zakulacený a většinou neúplný. Skulpturu tvoři radiální žebra, která jsou výrazná, a jejich

povrch může být $\mathrm{v}$ př́ípadě pozitivního otisku zakulacený, jsou oddělena úzkými drážkami. Koncentrické přírůstkové linie jsou viditelné především na ventrální části misek. Vrchol je drobný a pouze mírně převyšuje schránku. Přední ouško, pokud je zachováno, pokračuje v linii se zámkovým okrajem. Zadní ouško je od zadního okraje odděleno rýhou.

Výskyt: Nemojany H, Opatovice 4, Opatovice 8. 
Streblochondria praetenuis (KOENEN, 1879)

Obr. 2-1.

Misky středních rozměrů, oválného tvaru. Ouška mají elongátní morfologii, mohou se nacházet i oddělena od misek (Tab. 1, obr. 1). Misky jsou nejvíce konvexní ve střední části. V okrajích bývají dobře zachovalé. Přední a zadní okraj má stejný průběh od vrcholu, ventrální okraj je zakulacený a mírně zvlněný. Povrch tvoří radiálně paprsčitá žebra, která spolu s koncentrickými liniemi vytvářejí povrchovou skulpturu s jamkami na jejich styku. Ouška jsou výrazně oddělena od misek rýhami a mají stejnou povrchovou skulpturu. Vrchol je drobný a ostrý.

Výskyt: Dědice K, Opatovice 1, Opatovice 4, Opatovice 8 , Opatovice 10.

Podtřída: Heteroconchia HERTWING, 1895

Rod: Sanguinolites MCCOY, 1844

Sanguinolites sp.

Misky větších rozměrů (až $7 \mathrm{~cm}$ ). Jsou klenuté ve střední části a vyklenutí probíhá středem misek směrem k zadnímu okraji, kde jsou téměř ploché. Misky jsou protáhlé ve směru délky na úkor výšky misky. Zadní okraj misky je zaoblený, ventrální okraj je téměř rovný a plynule přechází v přední okraj misky. Vrchol je předsunutý, antero-dorzální okraj je mírně konkávní. Povrch je tvořen nepravidelně rozloženými př́růstkovými liniemi.

Výskyt: Nemojany H, Opatovice 1, Opatovice 4, Opatovice 6.

\section{Rod: Edmondia KonINCK, 1842}

Edmondia sp.

Středně velké až velké misky oválného tvaru. Vrcholy misek jsou tupé a ploché, výrazně nevystupují nad dorsální okraj, jsou umístěny víceméně uprostřed misky. Přední okraj má zřetelný anterodorzální výřez. Ventrální okraj přechází v širokém oblouku bez přerušení do mírně konvexního okraje zadního. Misky jsou mírně konvexní. Skulptura je tvořena jemnými koncentrickými liniemi a výraznými, pravidelnými koncentrickými valy, v zadní části misek jsou méně nápadné.

Výskyt: Ježkovice R3, Opatovice 1, Opatovice 4, Opatovice 6, Opatovice 10.

Podtřída: Cryptodonta NEUMAYR, 1884

Rod: Janeia KING, 1850

Janeia böhmi (SCHMIDT, 1910)

Misky jsou menších rozměrů, eliptické a inekvivalvní, protažené ve směru délky misky. Levá miska bývá obyčejně kratší. Dorzální okraj je dlouhý a rovný, zadní okraj je elongátní. Misky jsou málo vyklenuté. Přední okraj je zaoblený s výrazným antero-dorzálním výkrojem před drobným, méně nápadným vrcholem. Skulpturu tvoří plochá radiální žebra, která jsou při dobrém zachování omezena ostrými rýhami. Žebra jsou hustší v přední části misek. Misky jsou morfologicky variabilní, někteří autoři však uvažují o dimorfismu schránek (Řehoř - Řehořová 1972).

Výskyt: Opatovice 1a, Opatovice 4, Opatovice 6.
Podtř́ída: Palaeotaxodonta KOROBKOW, 1954

Rod: Polidevcia ČERNYŠEV, 1951

Polidevcia cf. sharmani ETHERIDGE, 1878

Misky jsou pouze malých rozměrů do $5 \mathrm{~mm}$. Inekvivalvní, rostrátní. Jsou mírně klenuté, rostrum je krátké a tupé, vzácně se zachovává celé. Vrchol je širší a umístěný více do středu. Ventrální okraj zaoblený. Skulpturu tvoří jemné, pravidelné koncentrické linie.

Výskyt: Opatovice 4, Pístovice Š.

\section{Polidevcia cf. attenuata (FLEMING, 1828)}

Misky malých rozměrů do $5 \mathrm{~mm}$. Rostrátní, inekvivalvní misky jsou mírně klenuté. Přední okraj misek je přímý a v pravidelném oblouku přechází do klenutého okraje spodního. Rostrum je dlouhé a tupě ukončené. Skulpturu tvoří pravidelné koncentrické linie.

Výskyt: Opatovice 4.

\section{Rod: Anthraconeilo GIRTY, 1912}

Anthraconeilo oblongum (HIND, 1897)

Drobné až střední, protáhle eliptické misky. Dorsální okraj je dlouhý, zámková linie probíhá paralelně s osou misek. Přední i zadní okraj je pravidelně klenutý a elongátní, přechází bez významnějšího úhlu do mírně klenutého ventrálního okraje. Konkávní průběh okraje misky vytváří v přední části mělký lalůček. Skulptura je tvořena velmi jemnými až nezřetelnými koncentrickými nitkovitými liniemi.

Výskyt: Dědice K, Hamiltony 1, Nemojany I, Opatovice 1, Opatovice 1a, Opatovice 4, Opatovice 6, Pístovice K.

\section{Rod: Palaeoneilo HaLl eT WHITFIELD, 1869}

Palaeoneilo luciniforme (PHILLIPS, 1836)

Drobné až středně velké misky poloelipsovitého tvaru. Zadní okraj je zaoblený, přední okraj je mírně konvexní a přechází plynule do silně klenutého, ventrálního okraje. Misky jsou značně klenuté, téměř kulovité. Vrchol je drobný a předsunutý. Skulptura je tvořena velmi jemnými koncentrickými liniemi.

Výskyt: Nemojany H, Opatovice 1, Opatovice 1a, Opatovice 4, Opatovice 6, Opatovice 10.

\section{Diskuze}

Výskyty spodnokarbonské mlží fauny jsou známy ze střední Evropy (Německa a Polska) i z kulmských pánví Turecka a Španělska. V rámci Českého masivu lze spodnokarbonskou (mlží) faunu srovnávat s faunou Nízkého Jeseníku, kde má však podle Kumpery (1983) ryze doprovodný ráz a je vertikálně vázána na moravické a hradecko-kyjovické souvrství. Obdobná společenstva mlžů byla detailně studována Żakowou (1958, 1966, 1971) ze spodnokarbonských sedimentů Svatokřížských a Sovích hor, kde byla popsána mnohem více diverzifikovaná společenstva mlžů. Poněkud odlišná spodnokarbonská mlží fauna se nachází i v kulmských pánvích Turecka (srv. Okan a Hoşgör 2007) a Španělska (Amler a Prins 1999), jeví však společné znaky ve výskytech myalinidních mlžů (Septimyalina sp.) a druhu Posidonia becheri. Německé výskyty v Rýnském břidličném pohoří a Harzu popisuje např. Nicolaus (1963), z této 
Tab. 1: Přehled mlží fauny vyskytující se na lokalitách v myslejovickém souvrství podle zjištěných druhů (sestaveno na základě kolekce V. Langa).

Tab. 1: Overview of bivalve fauna occurring at sites in Myslejovice Formation according to the identified species (compiled on the basis of a collection of V. Lang).

\begin{tabular}{|c|c|c|c|c|c|c|c|c|c|c|c|c|c|c|c|c|c|c|}
\hline & 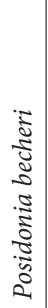 & 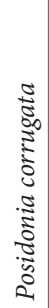 & 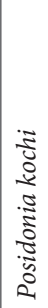 & 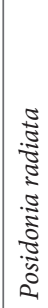 & 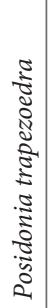 & 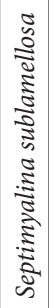 & 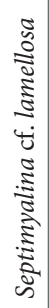 & 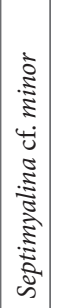 & 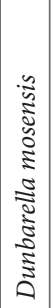 & 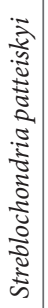 & 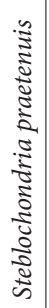 & 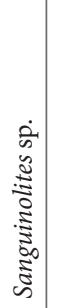 & 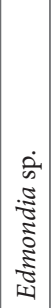 & 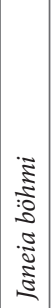 & 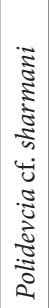 & 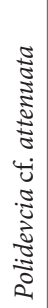 & 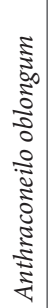 & 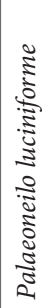 \\
\hline Dědice K & $\mathrm{X}$ & $\mathrm{X}$ & $\mathrm{X}$ & & $\mathrm{X}$ & & & $\mathrm{X}$ & & & $\mathrm{X}$ & & & & & & $\mathrm{X}$ & \\
\hline Hamiltony & $\mathrm{X}$ & & & & & & & & & & & & & & & & $\mathrm{X}$ & \\
\hline Ježkovice K & $\mathrm{X}$ & $\mathrm{X}$ & & & & & & & & & & & & & & & & \\
\hline Ježkovice R & $\mathrm{X}$ & $\mathrm{X}$ & & & & & & & $\mathrm{X}$ & & & & $\mathrm{X}$ & & & & & \\
\hline Lhota & & & & & & $\mathrm{X}$ & & & & & & & & & & & & \\
\hline Luleč & & & $\mathrm{X}$ & & & & & $\mathrm{X}$ & & & & & & & & & & \\
\hline Myslejovice & & & & & & & & & $\mathrm{X}$ & & & & & & & & & \\
\hline Nemojany Bl. Dol. & $\mathrm{X}$ & & & & & & & & & & & & & & & & & \\
\hline Nemojany $\mathrm{H}$ & $\mathrm{X}$ & & $\mathrm{X}$ & & & $\mathrm{X}$ & & & & $\mathrm{X}$ & & & & & & & & $\mathrm{X}$ \\
\hline Nemojany Ch & $\mathrm{X}$ & $\mathrm{X}$ & & & & & & & & & & & & & & & & \\
\hline Nemojany I & & & & & & & & & & & & & & & & & $\mathrm{X}$ & \\
\hline Olšany & $\mathrm{X}$ & $\mathrm{X}$ & & & & & & & & & & & & & & & & \\
\hline Opatovice 1 & $\mathrm{X}$ & $\mathrm{X}$ & $\mathrm{X}$ & $\mathrm{X}$ & $\mathrm{X}$ & $\mathrm{X}$ & $\mathrm{X}$ & $\mathrm{X}$ & & & $\mathrm{X}$ & $\mathrm{X}$ & $\mathrm{X}$ & $\mathrm{X}$ & & & $\mathrm{X}$ & $\mathrm{X}$ \\
\hline Opatovice 2 & $\mathrm{X}$ & $\mathrm{X}$ & $\mathrm{X}$ & & & $\mathrm{X}$ & $\mathrm{X}$ & $\mathrm{X}$ & & & & & & & & & & \\
\hline Opatovice 4 & $\mathrm{X}$ & $\mathrm{X}$ & $\mathrm{X}$ & $\mathrm{X}$ & $\mathrm{X}$ & $\mathrm{X}$ & $\mathrm{X}$ & $\mathrm{X}$ & & $\mathrm{X}$ & $\mathrm{X}$ & $\mathrm{X}$ & $\mathrm{X}$ & $\mathrm{X}$ & $\mathrm{X}$ & $\mathrm{X}$ & $\mathrm{X}$ & $\mathrm{X}$ \\
\hline Opatovice 6 & & $\mathrm{X}$ & $\mathrm{X}$ & & $\mathrm{X}$ & $\mathrm{X}$ & $\mathrm{X}$ & & & & & $\mathrm{X}$ & $\mathrm{x}$ & $\mathrm{X}$ & & & $\mathrm{X}$ & $\mathrm{X}$ \\
\hline Opatovice 8 & $\mathrm{X}$ & $\mathrm{X}$ & $\mathrm{X}$ & $\mathrm{X}$ & $\mathrm{X}$ & $\mathrm{X}$ & & & & $\mathrm{X}$ & $\mathrm{X}$ & & & & & & & \\
\hline \multicolumn{19}{|l|}{ Opatovice 9} \\
\hline Opatovice 10 & $\mathrm{X}$ & & $\mathrm{X}$ & & & $\mathrm{X}$ & $\mathrm{X}$ & $\mathrm{X}$ & $\mathrm{X}$ & & $\mathrm{X}$ & & $\mathrm{X}$ & & & & & $\mathrm{X}$ \\
\hline Opatovice 11 & $\mathrm{X}$ & & $\mathrm{X}$ & & & & $\mathrm{X}$ & $\mathrm{X}$ & & & & & & & & & & \\
\hline Pístovice K & $\mathrm{X}$ & & & & & & & & & & & & & & & & $\mathrm{X}$ & \\
\hline Pístovice K1 & $\mathrm{X}$ & $\mathrm{X}$ & & & & & & & & & & & & & & & & \\
\hline Pístovice Š & $\mathrm{X}$ & & & & & & & & & & & & & & $\mathrm{X}$ & & & \\
\hline Pístovice Š1 & $\mathrm{X}$ & $\mathrm{X}$ & $\mathrm{X}$ & & & & & & & & & & & & & & & \\
\hline Pístovice Ž & $\mathrm{X}$ & & & & & & & & & & & & & & & & & \\
\hline Radslavice & $\mathrm{X}$ & & & & & & & & & & & & & & & & & \\
\hline Rychtářov & $\mathrm{X}$ & $\mathrm{X}$ & & & & & & & & & & & & & & & & \\
\hline Kobylničky & & $\mathrm{X}$ & & & & & & & & & & & & & & & & \\
\hline
\end{tabular}

nacházejí jedinci druhu $P$. kochi ve větším množství, což by řadilo tuto lokalitu stratigraficky níže pod hranici goniatitové zóny Go $\beta_{\text {str }}$ zatímco Kumpera a Lang (1975) ji řadí výše, tedy do zón Go $\beta_{\mathrm{el}}$ - spodní Go $\beta_{\mathrm{mu}}$ goniatitové zonace. To může být způsobeno dozníváním ranějších druhů, což je doloženo i u goniatitů, kteří se na této lokalitě vyskytují (např. Goniatites crenistria PHILLIPS). Společný výskyt $P$. trapezoedra a $P$. becheri potvrzuje biostratigrafickou pozici na lokalitách Opatovice 2, 6, 8, 10, $11 \mathrm{v}$ intervalu zón Go $\beta_{\mathrm{mu}}-\mathrm{Go} \beta_{\mathrm{spi}}$. P. corrugata se vyskytuje na lokalitách Drahanské vrchoviny pouze ojediněle (Radslavice). Stratigraficky významné mohou být i druhy Streblochondria praetenuis (KOENEN) a Dunbarella mosensis KONINCK. Široké stratigrafické rozpětí rodu Dunbarella, začínající shodně s goniatitovou zónou cu II $\beta$ (Goniatites plicatilis - corpulentum) lze využít zejména při hranici tournai-visé. Streblochondria praetenuis (KOENEN) se vyskytuje v rozmezí zón becheri-mosensis a becheri-kochi, což koresponduje s hranicemi zón Goa až sv. hranice Goa ${ }_{4}$. Streblochondria praetenuis je známa z lokality Opatovice 4 a 8, kde je její výskyt vzácný. To lze zdůvodnit dozníváním jmenovaného druhu a postupným

oblasti rovněž vychází i biostratigrafická korelace podle Amlera (2004), který čerpal ze sbírkového materiálu např. Nicolause (opus cit.) a Klebelsberga (1912).

\section{Závěr}

Ve středoevropských kulmských faciích lze na základě zjištěných taxonů mlžů korelovat mlží zóny s goniatitovými (Amler 2004). V myslejovickém souvrství drahanského kulmu jsou zastoupeny zóny becheri - mosensis, becheri - kochi, corrugata - sulcata a trapezoedra - lepida (obr. 1).

Výskyt P. becheri na lokalitách Ježkovice R, Ježkovice K, Pístovice K, Pístovice Š, Pístovice Š1, Pístovice Ž, Nemojany Ch a Nemojany H odpovídá stratigrafické pozici zóny corrugata-sulcata, kterou Amler (2004) koresponduje s nejvyššími zónami Goo-Go $\beta_{\text {mu }}$. Kumpera a Lang (1975) však řadí lokalitu Pístovice Š výše do zóny Go $\beta_{\mathrm{spi}}-\mathrm{Go} \gamma_{1}$. Jako problematická se jeví lokalita Opatovice 4, kde se nahrazováním druhem Streblochondria patteiskyi NICOLAUS. Nevýhodou biostratigrafie dle mlžů je jejich značná vertikální distribuce při relativně malém množství počtu zástupců jednotlivých taxonů. Korelace výskytu mlžích zón $s$ goniatitovými zónami se prokázala jako užitečné vodítko, ale vzhledem ke značně variabilním podmínkám v rámci jednotlivých lokalit dochází k odchylkám, které je třeba přisoudit mimo jiné neúplnosti fosilního záznamu z daných lokalit.

Zjištěná mlží fauna představuje společenstvo organismů s bentickým nebo pseudoplanktonním stylem života. Nejvíce diverzifikované je na lokalitách Opatovice 4 a Opatovice 6 (tab. 1). Asociace spodnokarbonských mlžů na lokalitách v myslejovickém souvrství odpovídá ostatním společenstvům středoevropských kulmských facií, avšak na Drahanské vrchovině jsou tato společenstva mírně redukovaná. 


\section{Literatura}

Amler, R. W. (1994): The earliest European Streblochondriid Bivalves (Pteriomorphia; Late Famennian). - Annales de la Société géologique de Belgique, 117, 1, 1-17.

Amler, R. W. (2004): Bivalve biostratigraphy of the Kulm Facies (Early Carboniferous, Mississippian) in central Europe. - Newsletter of Stratigraphy, 40, 3, 183-207.

Amler, M. R. W. - Prins, C. F. W. (1999): Lower Carboniferous marine bivalves from the Cantabrian Mountains (Spain). - Scripta Geologica, 120, 1-45.

Dvořák, J. (1966): Zpráva o řešení stratigrafie spodního karbonu v kulmském vývoji na Drahanské vrchovině. - Zprávy o geologických výzkumech v r. 1964, 182-185.

Lehotský, T. (2008): Taxonomie goniatitové fauny, biostratigrafie a paleoekologie jesenického a drahanského kulmu. - MS, disertační práce, PřF MU Brno.

Klebelsberg, R. (1912): Die marine Fauna der Ostrauer Schichten. - Jahrbuch der k. k. geolischen Reichsanstalt, 62, 3, $462-556$.

Korn, D. (2010): Lithostratigraphy and biostratigraphy of the Kulm succession in the Rhenish Mountains. - Deutche Gesellschaft für Geowissenschaften, 161, 4, 431-453.

Kumpera, O. (1983): Geologie spodního karbonu jesenického bloku. - Knihovna Ústředního ústavu geologického, 59, 172 str.

Kumpera, O. - Lang, V. (1975): Goniatitová fauna v kulmu Drahanské vysočiny (moravskoslezská zóna Českého masívu). - Časopis Slezského muzea v Opavě, 24, 11-32.

Lang, V. - Pek, I. - Zapletal, J. (1979): Ichnofosilie kulmu jihovýchodní části Drahanské vrchoviny. - Acta Universitatis Palackianae Olomucensis, Facultas Rerum Naturalium, Geographica-Geologica, 62, 18, 57-96.

Nicolaus, J. H. (1963): Zur Stratigraphie und Fauna der crenistria-Zone im Kulm des Rheinischen Schiefergebirges. - Beihefte zum Geologischen Jahrbuch, 53, 246 str.

Okan, Y. - Hoşgör, I. (2007): Late Viséan - Early Namurian bivalves from the Zonguldak Coal Basin, Northwestern Turkey. Turkish Journal of Earth Sciences, 16, 225-240.

Řehoř, F. - Řehořová, M. (1972): Makrofauna uhlonosného karbonu československé části hornoslezské pánve. - Profil. 136 str.

Żakowa, H. (1958): Biostratygrafia utworów morskich dolnego karbonu z obszaru Wałbrzycha Miasta na Dolnym Sląsku. - Prace Instytutu Geologicznego, 19, 1-211.

Żakova, H. (1966): Poziom Goniatites crenistria PHILLIPS w okolicy Sokolca i Jugowa u podnóży Gór Sowich (Sudety środkowe). - Prace Instytutu Geologicznego, 43, 1-197.

Żakowa, H. (1971): Poziom Goniatites granosus w synklinie gałęzickiej (Góry Świętokrzyskie). - Prace Institutu Geologiczneho, $60,173$. 